\title{
Substitution Approach in Carbon Dioxide Emission Reduction Evaluation: Case Study on Geothermal Power Station Project Plan - Durkov (Košice Basin, Slovakia)
}

\author{
Branislav Fričovský, Stanislav Jacko Jr., Miroslava Popovičová, and Ladislav Tometz
}

\begin{abstract}
Application of substitution approach (fossil fuels heat and power production duty essential in high $\mathrm{CO}_{2}$ emissions is replaced by low-emissions based geothermal source in the same process at the same intensity) in $\mathrm{CO}_{2}$ emission reduction potential analysis for proposed cogeneration Ďurkov power station project is presented in the paper. Project can contribute with yearly $49891 \mathrm{tCO}_{2}$ of gross (a sum of $26811 \mathrm{tCO}_{2}$ from a heat and $23080 \mathrm{tCO}_{2}$ from a power production) or $49587 \mathrm{tCO}_{2}$ of real carbon dioxide savings. According to 40-years projected lifespan, achievable cumulative gross savings can reach 1,995 $\mathrm{MtCO}_{2}$ or $1,99 \mathrm{MtCO}_{2}$ of real carbon dioxide bulk mitigated.
\end{abstract}

Index Terms-Carbon dioxide savings, Ďurkov power station project, geothermal energy, implementation approach.

\section{INTRODUCTION}

Recent concern in environmental aspects of increasing energy demand, responding to global scientific and public consensus on disturbances in natural $\mathrm{CO}_{2}$ cycle, triggers actions and policies regarding renewable energy sources introduction into primary energy mix worldwide.

Pioneer studies in 1965 - 1969 defined the Durkov area as the most appropriate for geothermal power production in Slovakia [1]. However, there is no project that operates nowadays. Besides high T.D.S. content in brine, conflicts of interests or technical limitations, any existence of geothermal power station reflects typical feature of complex projects high investment costs and initial economical uncertainties [2]. $\mathrm{CO}_{2}$ savings derived environmental subsidies become relevant in project economical considerations.

Submission evaluates $\mathrm{CO}_{2}$ mitigation potential applying substitution approach for a cogeneration based - ORC geothermal power plant project in the Durkov area. Presented results can contribute on forthcoming enviro-economical studies once the project applies for global $\mathrm{CO}_{2}$ credits market. Authors try to explain methodology and provide essential basement and implications for preliminary environmental and cost-effectiveness analysis in akin projects worldwide.

Manuscript received November 5, 2012; revised January 6, 2013. The paper was written thanks to the support of the Operation Program Research and Development for the Project 26220220031 co-financed from the resources of the European Foundation of Regional Development.

Branislav Fričovský, S. Jacko, Jr. and L. Tometz are with the Institute of Geosciences, Faculty BERG, Technical University of Košice; Park Komenského 15, 04200 Slovakia (e-mail: branislav.fricovsky@tuke.sk; stano.jacko@tuke.sk; ladislav.tometz@tuke.sk)

M. Popovičová is with the Dept. of Furnaces and Thermal Technology, Faculty of Metalurgy, Technical University of Košice; Letná 9, 04200 Slovakia (e-mail: miroslava.popovicova@tuke.sk)

\section{KoŠICE BASIN - Climate AND PRIMARY ENERgy MiX}

\section{A. Climate}

Located in the SE part of the East Slovakian Basin, the Košice Basin is dominant in climate conditions of warm regions, split into moderately humid (south) and moderately dry subregions (north), all surrounded from the east and west with moderately warm, humid, highland-type subregion [3] (Fig. 1), defining 220 heating days and $9.5^{\circ} \mathrm{C}$ mean annual temperature [4].

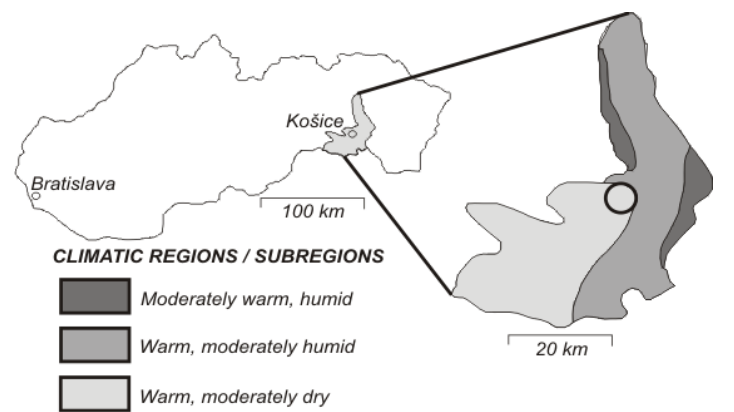

Fig. 1. The Košice Basin - schematic sketch and climatic regions.

\section{B. Primary Energy Mix - Electricity and Heat Supply}

Slovak Republic, high-advanced economy is still fossil fuels oriented, regarding a heat and electricity supply for industry or municipalities, where renewables cover 19,8 \% of power and less than $7 \%$ of heat production only (Table I) [5]. In the Košice Basin, considering district urban heat and power supply, fossil fuels control the whole market (Table II) [6].

\begin{tabular}{lcccc} 
TABLE I: PRIMARY ENERGY MIX - HEAT AND POWER SUPPLY (SLOVAKIA) \\
\hline \hline Primary energy & Black coal & N. Gas & Oil & Renewables \\
\hline Heat & $23 \%$ & $53 \%$ & $12 \%$ & $7 \%$ \\
Power & $15 \%$ & $6 \%$ & $1 \%$ & $19,8 \%$ \\
\hline \hline
\end{tabular}

TABLE II: PRIMARY ENERGY MIX - HEAT AND POWER SUPPLy (KOŠICE B.)

\begin{tabular}{lcccc}
\hline \hline Primary energy & Black coal & N. Gas & Oil & Renewables \\
\hline Heat & $85 \%$ & $15 \%$ & - & - \\
Power & $60 \%$ & $28 \%$ & $12 \%$ & - \\
\hline \hline
\end{tabular}

\section{III. Ďurkov Geothermal Power Station Project}

Geothermal sources in the Durkov area associate with Mesozoic carbonates at depths of $1250-2600 \mathrm{~m}$ [7], where temperature varies $100-150{ }^{\circ} \mathrm{C}$ (trend increases SE-wards). By now, three wells (GTD-1, GTD-2, GTD 3) are in a trial operation [8] identifying high saline fluids with total dissolved solids at $20-35 \mathrm{~g} . \mathrm{l}^{-1}$ and $0,07 \mathrm{~g} . \mathrm{l}^{-1}$ of free $\mathrm{CO}_{2}$ [9]. 
Recent power station project plans to operate geothermal power plant with 2 exploitation (GTD-2, GTD-3) and 1 reinjection (GTD-1) wells at total $115 \mathrm{~kg} . \mathrm{s}^{-1}$ extraction rate and wellhead pressure of 1,4 MPa [10]. Call for energy efficiency improvements predefined the project to operate as cogenerating - a power production waste heat is then used in optimized district heating grid. High geothermal salinity limits the station to operate as binary (Organic Rankine Cycle based). While in a regard to national directives the power production counts the whole year, the district heating is optimized for 220 days - a number that corresponds to required mean temperature interval of $-13^{\circ} \mathrm{C}$ to $+13^{\circ} \mathrm{C}$.

Output parameters are outdoor temperature and comfortable indoor temperature in the district heating controlled thus vary in time as extracted brine mass diverts for bypass to provide preheating high enough for a heat supply. While at minimum critical temperature $\left(\mathrm{T}_{\text {out }}=-13^{\circ} \mathrm{C}\right)$ the heat potential duty reaches $15844 \mathrm{~kW}_{\text {th }}$ and power turbine output counts $1654 \mathrm{~kW}_{\mathrm{e}}$, at maximum temperature $\left(\mathrm{T}_{\text {out }}=13{ }^{\circ} \mathrm{C}\right)$ the heat output decreases to $6628 \mathrm{~kW}_{\text {th }}$ and power produced in the turbine turns to $3100 \mathrm{~kW}_{\mathrm{e}}$ (tab. III) However, turbine of installed power output over $3394 \mathrm{~kW}_{\mathrm{e}}$ is required according to maximum output calculated for $\mathrm{T}_{\text {out }}$ of $2-4{ }^{\circ} \mathrm{C}[11]$.

TABLE III: POWER PLANT PROJECT - OUTPUT DESIGN CRITERIA VS. TOUT

\begin{tabular}{ccc}
\hline \hline $\mathrm{T}_{\text {out }}\left({ }^{\circ} \mathrm{C}\right)$ & Heat output $\left(\mathrm{kW}_{\mathrm{th}}\right)$ & Power output $\left(\mathrm{kW}_{\mathrm{e}}\right)$ \\
\hline-13 & 15884 & 1654 \\
0 & 10764 & 3358 \\
3 & 9788 & 3394 \\
13 & 6628 & 3100 \\
17 & - & 2840 \\
\hline \hline
\end{tabular}

Based on efficiency analysis of turbine inlet pressures and power output, a most proper working fluid for power turbine is n-Pentane, even of considerably higher costs in comparison to other fluids (e.g. Isobutane). N-Pentane allows the turbine to keep stable efficiency of $85 \%$. District heating system uses fresh water as a working fluid in a cycle [12].

If we accept a system to operate constant as a base-load, power capacity of $26,1 \mathrm{GW}_{\text {he }}$ and heat capacity of $83 \mathrm{GW}_{\text {hth }}$ are yearly obtainable for a public supply. Later in calculations, both outputs enter relations for $\mathrm{CO}_{2}$ reduction mitigation evaluation as energy duty.

\section{Methodology}

Several methods for $\mathrm{CO}_{2}$ emission reduction evaluation are introduced into praxis nowadays - e.g. [13], [14], mostly derived from peak-load analysis and substitution. The Durkov project, however, operates as base-load. Consequently, here is the reduction understood as a mitigation process [4], resulting from emittive fossil fuels substitution either in a heat and power production by low emittive renewable - geothermal, in the same process at the same intensity [15].

Let us state the gross savings $\left(\mathrm{CO}_{2 \mathrm{~g}}\right)$ in combined heat and power production are bound to covered energy duty $\left(\mathrm{Q}_{\mathrm{ed}}\right)$, local primary energy mix $\left(\mathrm{P}_{\mathrm{pem}}\right)$ defining substitution rate for each fossil fuel, and fossil fuels emission factor $\left(\mathrm{EF}_{\mathrm{ff}}\right)-(1)$

$$
C O_{2 g}=\sum\left(Q_{e d} \cdot P_{p e m} \cdot E F_{f f}\right)
$$

where: $\mathrm{CO}_{2 \mathrm{~g}}$ - yearly gross savings $\left(\mathrm{tCO}_{2} \cdot \mathrm{yr}^{-1}\right)$, $\mathrm{Q}_{\mathrm{hp}}$ - heat and power duty (TJ.yr ${ }^{-1}$ or MWe.yr $\left.{ }^{-1}\right), \mathrm{P}_{\mathrm{pem}}$ - primary energy mix proportion (-), $\mathrm{EF}_{\mathrm{ff}}-$ carbon dioxide emission factor of fossil fuels $\left(\mathrm{tCO}_{2} \cdot \mathrm{TJ}^{-1}\right.$ or $\left.\mathrm{tCO}_{2} \cdot \mathrm{MWe}^{-1}\right)$.

Operation of geothermal power plant defines emissions produced $-\mathrm{CO}_{2 p}$ (2) during its run, controlled by duty of both processes $\left(\mathrm{Q}_{\mathrm{ed}}\right)$ and emission factor of geothermal fluid $\left(\mathrm{EF}_{\mathrm{geo}}\right)$ calculated from hydrogeochemical sampling:

$$
C O_{2 p}=\sum\left(Q_{e d} \cdot E F_{g e o}\right)
$$

where: $\mathrm{CO}_{2 \mathrm{p}}-$ yearly $\mathrm{CO}_{2}$ produced at the station $\left(\mathrm{tCO}_{2} \cdot \mathrm{yr}^{-1}\right)$, $\mathrm{Q}_{\mathrm{hp}}$ - heat and power duty $\left(\mathrm{TJ}^{\mathrm{yr} r^{-1}}\right.$ or MWe.yr $\left.{ }^{-1}\right), \mathrm{EF}_{\text {geo }}-$ emission factor of geothermal source $\left(\mathrm{tCO}_{2} \cdot \mathrm{TJ}^{-1}\right.$ or $\mathrm{tCO}_{2} \cdot \mathrm{MWe}^{-1}$ )

Subtraction of $\mathrm{CO}_{2}$ produced from gross savings itinerary results in yearly real carbon dioxide savings $-\mathrm{CO}_{2 \mathrm{r}}(3)$ :

$$
\mathrm{CO}_{2 r}=\mathrm{CO}_{2 g}-\mathrm{CO}_{2 p}
$$

where: $\mathrm{CO}_{2 \mathrm{r}}$-yearly real carbon dioxide savings $\left(\mathrm{tCO}_{2} \cdot \mathrm{yr}^{-1}\right)$, $\mathrm{CO}_{2 \mathrm{~g}}$ - yearly gross $\mathrm{CO}_{2}$ savings $\left(\mathrm{tCO}_{2} \cdot \mathrm{yr}^{-1}\right), \mathrm{CO}_{2 \mathrm{p}}$ - yearly $\mathrm{CO}_{2}$ savings produced at the site $\left(\mathrm{tCO}_{2} \cdot \mathrm{yr}^{-1}\right)$.

If the average lifetime $\left(\mathrm{LT}_{\mathrm{gp}}\right)$ of cogeneration projects at 40 years is accepted [6], real savings expected at the end of operation period are projected as cumulative $-\mathrm{CO}_{2 \mathrm{r}_{-} \mathrm{c}}$ (4):

$$
\mathrm{CO}_{2 r_{-} c}=C \mathrm{O}_{2 r} \cdot L T_{g p}
$$

where: $\mathrm{CO}_{2 r_{-}-}$- cumulative real savings $\left(\mathrm{tCO}_{2}\right), \mathrm{CO}_{2 \mathrm{r}}$ - yearly real $\mathrm{CO}_{2}$ savings $\left(\mathrm{tCO}_{2} \cdot \mathrm{yr}^{-1}\right), \mathrm{LT}_{\mathrm{hp}}-$ lifetime (yr)

Substitution of yearly gross savings into (4) with preserved lifetime $\mathrm{LT}_{\mathrm{gp}}$ turns to cumulative gross savings $\left(\mathrm{CO}_{2 \mathrm{~g}_{\mathrm{c}}}\right)$. A ratio of real cumulative over gross cumulative savings expresses in reduction effectiveness $\eta_{R}(5)$ [16]:

$$
\eta_{R}=\left(\frac{C O_{2 r_{-} c}}{C O_{2 g_{-} c}}\right) \cdot 100
$$

where: $\eta_{R}-$ reduction effectiveness (\%), $\mathrm{CO}_{2 r_{c} \mathrm{c}}-$ cumulative real savings, $\mathrm{CO}_{2 \mathrm{~g} \_\mathrm{c}}-$ cumulative gross savings.

\section{RESULTS AND COMMENTS}

\section{A. Carbon Dioxide Savings}

Substitution approach expects the power station project to supply energies constantly 24 hours a day, as in a case of conventional combined heat - and - power plants of a base-load service.

In both processes, the substituted bulk of energy duty equals $100 \%$ with proportion related to primary energy mix for heat and power (Table II). In a heat production savings, the accepted duty $\left(\mathrm{Q}_{\mathrm{dh}}\right)$ of $83 \mathrm{GW}_{\text {hth }}$ equals 298 , 4 TJ yearly the project is able to cover. Substitution of PEM and emission factors typical for Slovak Republic [17] - [18] (Table IV) into (1) defines yearly gross $\mathrm{CO}_{2}$ savings from a heating section of $26811 \mathrm{tCO}_{2} \cdot \mathrm{yr}^{-1}$, as a result of partial coal (24349 $\left.\mathrm{tCO}_{2} \cdot \mathrm{yr}^{-1}\right)$ and natural gas $\left(2461 \mathrm{tCO}_{2} \cdot \mathrm{yr}^{-1}\right)$ removal (Fig. 2) 
TABLE IV: EMISSION FACTORS AND GROSS CARBON DIOXIDE SAVINGS

\begin{tabular}{ccccc}
\hline \hline Fossil fuels & $\begin{array}{c}\text { Emission } \\
\text { factor } \\
{\left[\mathrm{t} . \mathrm{TJ}^{-1}\right]}\end{array}$ & $\begin{array}{c}\text { Emission } \\
\text { factor } \\
{\left[\mathrm{t}_{\mathrm{MW}}{ }^{-1}\right]}\end{array}$ & $\begin{array}{c}\mathrm{CO}_{2 \mathrm{~g}} \text { (heat) } \\
{\left[\mathrm{tCO}_{2} \cdot \mathrm{yr}^{-1}\right]}\end{array}$ & $\begin{array}{c}\mathrm{CO}_{2 \mathrm{~g}} \\
(\mathrm{power}) \\
{\left[\mathrm{tCO}_{2} \cdot \mathrm{yr}^{-1}\right]}\end{array}$ \\
\hline Total coal & 96 & 1,04 & 24349 & 16255 \\
Natural gas & 55 & 0,55 & 2461 & 4011 \\
Oil products & - & 0,9 & - & 2813 \\
Geothermal & 0,27 & 0,002 & - & - \\
\hline \hline
\end{tabular}

Analogously according to (1) in a power production section, substitution of related emission factors (Table IV) and proportion factors (Table II) for partial yearly gross $\mathrm{CO}_{2}$ reduction turns to total $23080 \mathrm{tCO}_{2} \cdot \mathrm{yr}^{-1}$ removal potential as a sum of partial emissions avoided from substitution of different fossil fuels (Table IV). A sum of bulk reduction from heat and power production defines then total yearly gross savings $-\mathrm{CO}_{2 \mathrm{~g}}$ of $49891 \mathrm{tCO}_{2} \cdot \mathrm{yr}^{-1}$ (Fig. 2).

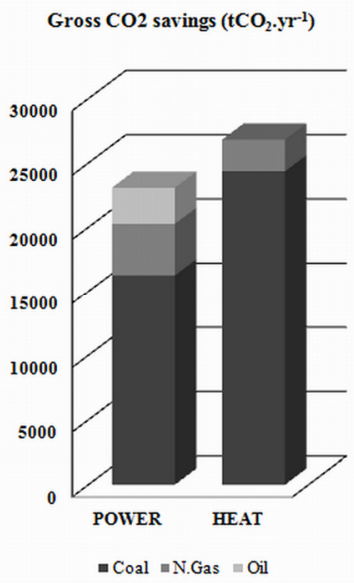

Fig. 2. Graphic display of partial gross $\mathrm{CO}_{2}$ savings in power and heat production

Observed contrasts in partial $\mathrm{CO}_{2}$ savings clearly reflect proportion of fossil fuels on heat and power production as well as correspond to various emission factors.

Each installation and operation of geothermal power plant defines a need for $\mathrm{CO}_{2}$ related to utilizing of geothermal fluids definition. The carbon dioxide produced (2) then reflects hydrochemistry of thermal fluids, essentially free $\mathrm{CO}_{2}$ compound and functions energy duty the fluid covers in a heat $\left(\mathrm{Q}_{\mathrm{ed}}=298,4 \mathrm{TJ}\right)$ and power $\left(\mathrm{Q}_{\mathrm{ed}}=26050 \mathrm{MW}_{\mathrm{he}}\right)$ production with calculated [19] emission factor of thermal fluid for both processes (table IV). Solution of (2) gives then 132 t. $\mathrm{CO}_{2} \cdot \mathrm{yr}^{-1}$ of carbon dioxide produced at the station $\left(\mathrm{CO}_{2 \mathrm{p}}\right)$ as a sum of partial emissions on a heat production $\left(80 \mathrm{tCO}_{2} \cdot \mathrm{yr}^{-1}\right)$ and power production $\left(52 \mathrm{tCO}_{2} \cdot \mathrm{yr}^{-1}\right)$ side.

With total yearly gross savings $\left(\mathrm{CO}_{2 \mathrm{~g}}=49891 \mathrm{tCO}_{2} \cdot \mathrm{yr}^{-1}\right)$ and in-situ emissions produced during utilization $\left(\mathrm{CO}_{2 \mathrm{p}}=\right.$ $132 \mathrm{tCO}_{2} \cdot \mathrm{yr}^{-1}$ ) predicted, solution of (3) defines then real carbon dioxide emissions mitigated $\left(\mathrm{CO}_{2 \mathrm{r}}\right)$ itinerary at a level of $49578 \mathrm{tCO}_{2} \cdot \mathrm{yr}^{-1}$. As emissions potentially produced at the station represent $0,2 \%$ from a bulk saved, the gap is almost negligible and the fluid is considered emissions- inactive [15].

Recent design of combined heat and power geothermal plants expects projects to operate at least for 40 years [20], a period that is set as lifespan ( $\left.\mathrm{LT}_{\mathrm{gp}}\right)$ to enter calculations of cumulative gross $\left(\mathrm{CO}_{2 \mathrm{~g}_{-} \mathrm{c}}\right)$ and real $\left(\mathrm{CO}_{2 \mathrm{r}_{-} \mathrm{c}}\right) \mathrm{CO}_{2}$ savings(4). Relation understands cumulative savings as itinerary of emissions the project mitigated at the end of operation, and calculates with both, gross $\left(\mathrm{CO}_{2 \mathrm{~g}}\right)$ and real $\left(\mathrm{CO}_{2 \mathrm{r}}\right)$ bulks. As a result, 1,995 $\mathrm{MtCO}_{2}$ of gross cumulative or $1,990 \mathrm{MtCO}_{2}$ of real cumulative savings are expected for the project (Fig. 3, table V) in case the system operates constantly as expected for a base-load supply.

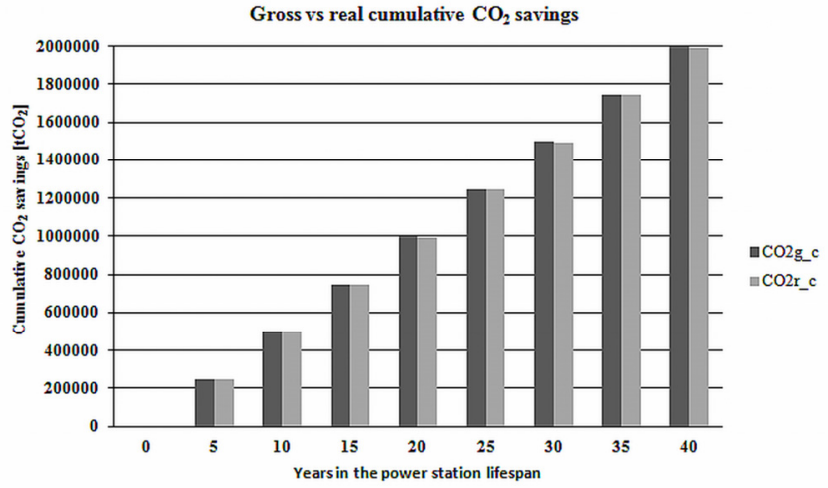

Fig. 3. Screen of cumulative real $\mathrm{CO}_{2}$ savings

TABLE V: SUMMARIZING TABLE ON CARBON DiOXIDE SAVINGS

\begin{tabular}{lcccc}
\hline \hline Value & $\begin{array}{c}\text { Gross } \mathrm{CO}_{2} \\
\text { savings } \\
{\left[\mathrm{MtCO}_{2}\right]}\end{array}$ & $\begin{array}{c}\text { Real CO} \\
\text { savings } \\
{\left[\mathrm{MtCO}_{2}\right]}\end{array}$ & $\begin{array}{c}\text { Power } \\
\text { production } \\
{\left[\mathrm{GW}_{\mathrm{h}}\right]}\end{array}$ & $\begin{array}{c}\text { Heat } \\
\text { production } \\
{[\mathrm{TJ}]}\end{array}$ \\
\hline Yearly & 0,0498 & 0,04975 & 26,1 & 298,4 \\
Cumulative & 1,995 & 1,990 & 1044 & 11936 \\
\hline \hline
\end{tabular}

\section{B. Environmental Economics Considerations}

Every geothermal project consideration meets unique limits regarding economical investment aspects. Investment costs in power-plant projects compose of a) exploration and resource confirmation, b) borehole drilling campaign, c) surface facilities and infrastructure emplacement and d) power plant design [21]. If we assume overall installation costs for a project for both, power and heat production at -6 $400 € . \mathrm{kW}^{-1}$, and add to an investment analysis expected operation and maintenance costs at $190 € . \mathrm{kWe}^{-1} \cdot \mathrm{yr}^{-1}$ [22], with optimized installed plant for 40 years projected lifespan at installed capacity of $3500 \mathrm{~kW}_{\mathrm{e}}$ and heat production installed capacity of $16 \mathrm{MW}_{\text {th }}$, investment costs may roughly reach 64,6 mil. $€$. This is an amount potential developer (private or national-owned) should consider in preliminary economic feasibility studies. By a contrast, a mean selling price of $0,03 € . \mathrm{kWh}^{-1}$ for electricity and $15 € . \mathrm{GJ}^{-1}$ can be expected in local conditions [23]. Additionally, with yearly real carbon dioxide savings known (49 $578 \mathrm{tCO}_{2}$ ), project can apply for environmental government subsidies regarding a $\mathrm{CO}_{2}$ carbon credit market at a level of $6 € \cdot \mathrm{t}^{-1}$ [5]. Yearly environmental subsidies then can contribute with 0,3 mil. $€$ on benefits side. A simple payback period calculated is then 2,32 years. However, such an analysis is clearly preliminary and detailed study is needed, where yearly incomes will depend on initial energy production and then break-away energy prices.

\section{National Reflections - Towards the EU Road Map}

National targets for EU member countries regarding 
introduction of renewables into primary energy mix in heat and power production defined proportion the Slovak Republic is supposed to achieve in 2020 for $14 \%$ on heat and $31 \%$ on power production [24]. Set-up targets are mandatory to meet under optional legal and financial penalties.

By now, renewables share $7 \%$ on heat and $19,8 \%$ on power (large hydro included) or 2,3\% (without large hydro plants) [5].

In case the project will operate, yearly power supply for a grid will reach $26,1 \mathrm{GW}_{\text {he. In primary energy mix we subtract }}$ the electricity produced from recent proportion of fossil fuels according to their share in electricity sector. As the total electricity generated yearly counts $26155 \mathrm{GW}_{\text {he, }}$ geothermal project power supply will take $0,1 \%$. Then, proportion of renewables will increase for $19,9 \%$ (large hydro included) or 2,4\% (without large hydro).

Actual geothermal yearly heat production in Slovakia reaches $144 \mathrm{TJ}$ defining its $0,3 \%$ proportion on total national heat supply (42 $210 \mathrm{TJ})$. Constant co-generated geothermal heat delivery from a project into a mix calculated for $298,4 \mathrm{TJ}$ yearly, balanced with energy mix related subtraction of coal and gas in a heat delivery, will lead to increase of geothermal proportion up to $1,05 \%$ and increase of renewables share on heat production from $7,04 \%$ to $7,8 \%$ (Fig. 4).

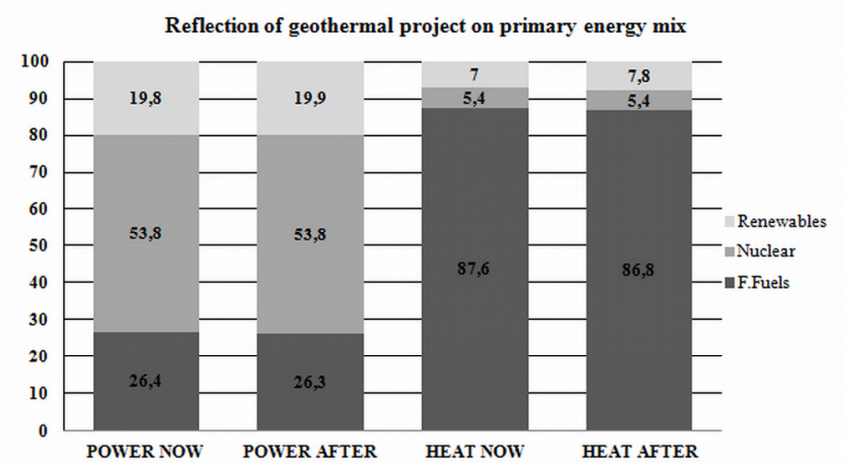

Fig. 4. Impact of geothermal system implementation for a power and heat supply renewable contribution towards the EU road map.

Observed increase of renewables proportion on heat and power national market imply the geothermal sector may not be able to cover the gap between recent situation and targets in the EU road map individually. However, while the Košice Basin is among three perspective localities for a geothermal power supply [25], thus possibilities of growth in geothermal power are rather unlikely, 26 areas perspective for geothermal heat production are identified [26] with a total thermal potential of $6653 \mathrm{MW}_{\text {th }}$ [27], providing a background high enough for rapid improvements. Then, every national progress towards the EU road map targets is a question of government financial and technical support supposed-to-be motivated by moral, legal and environmental merits.

\section{Limitations and Adds}

Authors accent the study is a background for potential ongoing detailed research. Additional approach is definitely needed considering operation characteristics of geothermal, combined heat and power binary plant projected, as well as detailed economic and environmental-economic analysis of a market is necessary. Data used in calculations of carbon dioxide savings are kept constant in time, however, they may seasonally vary.

\section{CONCLUSIONS}

The substitution approach for carbon dioxide savings evaluation is presented in the paper on a case study on actual considered geothermal power plant project in the Durkov area, Košice Basin, eastern Slovakia. Later on, results are nominally analyzed and reflected regarding project environmental economics and impact for a national primary energy mix scheme towards the EU road map set-up targets.

Essential philosophy of the approach understands reduction as a mitigation-substitution process, within that $\mathrm{CO}_{2}$ intensively emittive fossil fuels are replaced with a renewable source of low $\mathrm{CO}_{2}$ emissions intensity in the same process and nominal duty. Analyzed model of a power plant operates as binary and base-load at combined, heat-and-power principle.

Introduction of the power plant into the heat and power grid may contribute with overall yearly gross $49891 \mathrm{tCO}_{2}$ mitigated, out of that $28811 \mathrm{tCO}_{2}$ refer to fossil fuels substitution in a heat and $23080 \mathrm{tCO}_{2}$ to power production sector (corresponding to actual fossil fuels regional energy mix proportion). Use of geothermal fluids leads to yearly potential in-situ emissions of carbon dioxide evaluated for $132 \mathrm{tCO}_{2} \cdot \mathrm{yr}^{-1}$ characterizing fluid as carbon-inactive. After subtraction of emissions produced from a gross itinerary, yearly real $\mathrm{CO}_{2}$ savings calculated drop negligibly down to $49578 \mathrm{tCO}_{2}$. If the 40 years lifespan of a geothermal project is accepted, cumulative savings at the end of a period increase up to $1,995 \mathrm{tCO}_{2}$ of gross or $1,990 \mathrm{tCO}_{2}$ of real bulk reduced. Carbon dioxide emission reduction potential then reflects in potential environmental subsidies at yearly rate of 0,3 mil. $€$, contributing on a project's payback period shortening.

Even of proven environmental impact and relatively low (preliminary) calculated payback period (2,32 years), introduction of projected plan producing $26,1 \mathrm{GW}_{\text {he }}$ of power and 298,4 TJ of heat yearly will not dramatically effect national primary energy mix. Observed $0,1 \%$ upturn in renewables proportion on power and $0,8 \%$ on a heat production will not solve a nations' rough path to meet EU set-up targets regarding renewables proportion on energy mix.

\section{ACKNOWLEDGMENT}

Authors would like to thank Dipl. Eng. Silvia Lukačínová, Ph.D. (Institute of Geosciences, TUKE, Slovakia), prof. Dušan Holoubek, Ph.D. (Dept. Of Furnaces and Thermal Technology, TUKE) and Dr. Anett Blischke (Icelandic Geological Survey) for a worthful support and consultations.

\section{REFERENCES}

[1] O. Franko, I. Marušiak, I. Lizoň, L'. Mateovič, andA. Chomová, Report on Heat Flow Distribution and Geothermal Energy Sources in SSR (Western Carpathians) for Years 1987 - 1980, Technical report, Slovak Geological Survey, Bratislava, Slovakia, 1982. 
[2] A. Vranovská, V. Beňovský, V. Drozd, O. Halás, and O. Váňa, Investigation for Geothermal Energy in the Town Košice, Slovak Republic, Technical report, Slovak Geological Survey, Bratislava, Slovakia, 2000

[3] M. Lapin, P. Faško, M. Melo, P. Štastný, and J. Tomlain, "Climatic regions in Slovakia," Atlas of the Slovak Republic-text notes $2^{\text {nd }}$ ed., L. Miklós Ed., chapter 4.27, pp. 94-95, Ministry of Environment of the Slovak Republic, Bratislava, Slovakia, 2002.

[4] O. Bochníček, M. Lapin, and L. Soták, "Mean annual summer, frosty and heating days and annual temperature," Atlas of the Slovak Republic - text notes $2^{\text {nd }}$ ed., L. Miklós Ed., chapter 452, pp. 97-98, Ministry of Environment of the Slovak Republic, Bratislava, Slovakia, 2002.

[5] J. Mládek, "Industry and green energy adaptability potential of the Slovak Republic," Enviromagazin, vol. 6, pp. 23-27, 2011.

[6] "Update on National Energy Strategy," Technical report, Ministry of Economy of the Slovak Republic, Bratislava, Slovakia, 2011.

[7] A. Vranovská, "The Košice Basin - Durkov geothermal structure regional hydrogeothermal evaluation," Technical report, Slovak Geological Survey, Bratislava, Slovakia, 1999.

[8] V. Beňovsky, V. Drozd, O. Halás, O. Váňa, and A. Vranovská, “Trial operation tests at the Durkov hydrogeothermal structure," Podzemná voda, vol. 7 , no. 2, pp. 157-163, January, 2001.

[9] D. Bodiš, J. Michalko, and D. Rapant, "Hydrochemical tests on GTD-2 borehole,” Manuscript, Slovak Geological Survey, Bratislava, Slovakia, 1999.

[10] M. Popovičová, "Design criteria for a proposed CHP Geothermal Plant Durkov, Slovakia - analysis and modeling of ORC power plant and district heating system," M. Sc. Thesis, RES, The School for Renewable Energy Science, Akureyri, Iceland, 2010.

[11] M. Popovičová and D. Holoubek, "Binary geothermal power plant using n-Pentane at Durkov, Slovakia," Acta Metalurgica Slovaca, vol. 1, no. 2, pp. 172-175, 2012.

[12] M. Popovičová, "Design and comparison of thermodynamic properties of the geothermal binary cycle system operated in cogeneration," Minimum PhD thesis, Faculty of Metalurgy, Technical University of Košice, 2012.

[13] Z. Keyan, H. Jinshu, and J. Peigi, "Potential reduction in $\mathrm{CO}_{2}$ emissions by geothermal heating Beijing, Tianjin and Xianyang by 2020," Workshop for decision makers on direct use of geothermal resource in Asia, pp. 154-160, Tianjin, China, 2008.

[14] I. B. Fridleifsson, R. Bertani, J. W. Lund, and L. Rybach, "The possible role and contribution of geothermal energy to the mitigation of climate change," IPCC Scoping Meeting on Renewable Energy Sources Proceedings, pp. 59-80, Luebeck, Germany, 2008.

[15] B. Fričovský, M. Friedmannová, and P. Skibová, "Carbon dioxide savings benefits evaluation of hypothetical geothermal district heating system implementation in the Bešeňová elevation region; Liptov Basin, northern Slovakia," presented at Ecology and Environmentalistics, Zvolen, Slovakia, May 24-25, 2012.

[16] B. Fričovský, S. Jacko Jr., M. Chytilová, and L. Tometz, "Geothermal energy of Slovakia - $\mathrm{CO}_{2}$ emission reduction contribution potential (background study for conservative and non-conservative approach)," RESpect VII - International conference on Renewable Energy Sources proceedings, pp. 146-158, Poráč Park, Slovakia, 2012.

[17] J. Fazekaš, E. Hantabál, I. Lauková, T. Putoš, and S. Zamboy, "Final technical report on Handlova coal mine," Manuscript, Slovak Geological Survey, Bratislava, Slovakia, 1999.

[18] Weightened average values of heating fuels parameters in Slovak industry, Slovak Gas Company, Bratislava, Slovakia, 2011.

[19] B. Fričovský, S. Jacko Jr., M. Chytilová, and L. Tometz, "Geothermal energy of Slovakia $-\mathrm{CO}_{2}$ emission reduction contribution potential (background study for conservative and non-conservative approach)," Acta Montanistica Slovaca, vol. 17, no. 3, pp. 173-185, 2012.

[20] A. Holm, L. Blodgett, D. Jennejohn, and K. Gawell, "Geothermal Energy - international market update," Technical report, Geothermal Energy Association, Washington DS, USA, 2010.

[21] A. Kagel, A handbook on the Externalities, Employment and Economics of Geothermal Energy, Geothermal Energy Association, pp 65, Washington DC, USA, 2006.

[22] C. J. Bromley, M. A. Mongillo, B. Goldstein, G. Miriart, R. Bertani, E. Huenges, H. Muraoka, A. Ragnarsson, J. Teszter, and V. Zui, "Contribution of geothermal energy to climate change mitigation: the IPCC renewable energy report," in Proc. World Geothermal Congress 2010, paper No. 0225, pp. 1-5, Bali, Indonesia, April 25-29, 2010.

[23] B. Fričovský, "Modeling of quantitative and qualitative parameters of the Bešeňová elevation hydrogeothermal structure; applications for local scale geothermal infrastructure enhancement," M.Sc. thesis,
Institute of Geosciences, Technical University of Košice, Košice, Slovakia, 2011.

[24] A. Zervos, Ch. Lins, L. Tesniere, and E. Smith, "Mapping Renewable Energy Pathways towards 2020 - EU Roadmap" Technical report, European Renewable Energy Council, Brussels, Belgium, 2011.

[25] A. Vranovská, V. Drozd, and O. Halás, "Geothermal energy utilization - economic potential of Košice Basin,” Mineralia Slovaca, vol. 32, no. 3, pp. 311-313, 2000.

[26] M. Fendek, A. Remšík, and M. Král, "Nature of geothermal resources in Slovak Republic," Slovak Geological Magazine, vol. 5, no. 1-2, pp. 121-130, 1999.

[27] M. Fendek, A. Bágelová, and M. Fendeková, "Geothermal energy worldwide and in Slovakia," Podzemná Voda, vol. 17, no. 1, pp. 74-83, 2011.

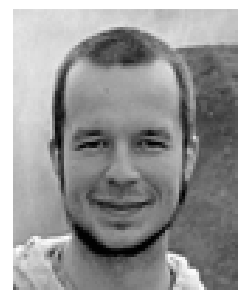

Branislav Fričovský was born in Košice - Slovakia, $30^{\text {th }}$ April 1985, graduated in Geology and regiona developemt (Bc., B.S.) in 2008 at the Technichal University of Košice, Slovakia. Later in 2010 he graduated at RES | The School for Renewable Energy Science, Akureyri - Iceland, with the Dipl. Ing. (M.S.) in Geothermal energy specialization. Then, author continued his studies at TUKE and graduated as Dipl. Eng or M.Sc. (M.S.) in geological engineering. Since september 2012 he is an internal Ph.D. student at the Institute of Geosciences, Technical University of Košice, with a focus on geothermal energy and hydrogeology.

His publications scope geothermal energy potential and geothermics of northern Slovakia mostly, however, he co-operates on projects and publications related to geothermal energy based carbon dioxide saving in Slovakia regionally. Detailed research interests are in environmental aspects of geothermal projects implementation in northern Slovakia, hydrochemistry, thermodynamics, and static or dynamic modeling of the Bešeňová elevation hydrogeothermal structure (Liptov Basin, N. Slovakia).

Dipl. Eng. Fričovský, M.S. is a member of Slovak Association of Hydrogeologists and Slovak Mining Society. He co-operates on EU founded project 26220220031. In 2011, he was awarded the Master's Thesis of the Year by the Slovnaft a.s. company.

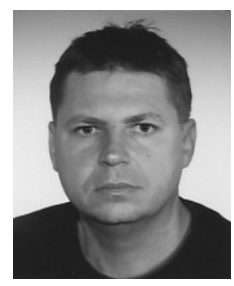

Stanislav Jacko Jr. was born in 1969 in Košice, graduated at the Dept. of Geology and Mineralogy at the Technical University of Košice in 1993, achieving the Dipl. Eng.. (M.Sc.) degree in Geological prospection and survey. Since then, he was a researcher at the Slovak Geological Survey until 2002, during which he completed scientific degree of Ph.D in structural geology. In 2002 he joined the Dept. of Geology and Mineralogy as a lecturer and research fellow. In year 2008 he was appointed the Associate Professor in geology and structural geology.

Even his primary research activities focus at structural and regional geology or tectonics, a list of publications includes papers and conference contributions scoping the geothermal energy of Slovakia as well, related mostly to static $2 \mathrm{D}-3 \mathrm{D}$ reservoir modeling.

Assoc. Prof. Jacko is a stable chair in the Academic Senate of the Faculty of Mining, Ecology, Process Control and Geotechnologies, member of Bachelor's, Master's and $\mathrm{PhD}$ examining commissions at the Institute of Geosciences, as well as a supervisor for all three programs. In $2009-2010$, he was a head of Dept. of Geology and Natural Sources at the Ministry of Environment of the Slovak Republic. As the Associate Professor, he is a Ministry of Education acknowledged supervisor in undergraduate, graduate and post-graduate programs at the Technical University of Košice.

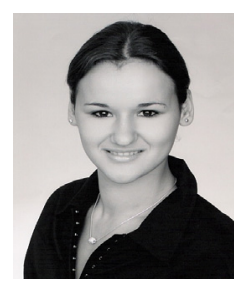

Miroslava Popovičová Was born in 1985 in Košice, graduated in Thermal Energy and Gas Industry program at Dept. of Furnaces and Thermal Technology at the Technical University of Košice in 2008 awarded with a Bc. (B.Sc.) degree. After that she successfully graduated in Geothermal energy specialization at the RES | The School for Renewable Energy Science, Akureyri, Iceland in 2010, achieving the M.S. (M.Sc.) degree, prior to graduation as Ing. (M.S., M.Sc.) in Energy study program at Dept. of Furnaces and Thermal Technology at the Technical University of Košice in 2010. Since September 2010 she is an internal Ph.D. student at Dept. Of Furnaces and Thermal 
Technology in study program of Energy, with a focus on design and criteria optimalization of ORC - binary based geothermal systems.

Her primary research activities relate to definition, optimization and modeling of design criteria for binary and cogeneration-operated geothermal power plants, with a most of the scope set at the Košice Basin. Affine to her research topics, she published or submitted several papers about the topic.

Dipl. Eng. Popovičová is a member of Dept. of Furnaces and Thermal Technology as internal doctoral student, being active in research and lecturing.

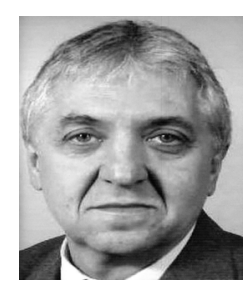

Ladislav Tometz was born in Košice (Slovakia) in 1953 graduated and was awarded with the Dipl. Eng. (M.Sc.) degree in Mining geology at the Faculty of Mining, Technical University of Košice. After the study he spent fifteen years in praxis and applied research, focused at hydrogeology, environmental geology and engineering geology. In 1995 he became a lecturer at the Department of Geology and Mineralogy - Technical University of Košice. Later in
2000, Ladislav Tometz successfully gained his Ph.D in Environmental geology and Hydrogeology. In 2008 he was appointed the Associate Professor in hydrogeology, environmental geology and engineering geology.

His publications focus at environmental threat, pollution or redevelopment of hydrogeological environment and shallow soils, regional evaluation of hydraulic rock properties and groundwater movement. A most of published works scope, however, utilization, source management or evaluation and preservation of shallow to deep groundwater reservoirs.

Assoc. Prof. Tometz was a head of Department of Geology and Mineralogy (predecessor of current Institute of Geosciences) at the Technical University of Košice in $2002-2007$. Now he is active as a chair in Slovak Hydrogeological Association and a corresponder and reviewer of the Groundwater Journal (the journal of Slovak Hydrogeological Association). Since awarded with the PhD., he also became stable member of examining commission for Bachelor's, Master's and PhD programs at the Technical University of Košice and the Commenius University in Bratislava. As the Associate Professor, he is a Ministry of Education acknowledged supervisor in undergraduate, graduate and post-graduate programs at the Technical University of Košice. 